\title{
The problems of application of the laws on regulated purchases No. 44-FZ and No. 223-FZ when reorganizing legal entities
}

\author{
Vitaliy Peshkov ${ }^{1, *}$, Tatiana Doroshenko ${ }^{2}$, and Irina Sukhanova ${ }^{2}$ \\ ${ }^{1}$ Irkutsk National Research State University, 664074, Lermontov str., 83, Irkutsk, Russia \\ ${ }^{2}$ Baikal State University, 664003, Lenin str., 11, Irkutsk, Russia
}

\begin{abstract}
The purpose of the study is to analyze the problems of applying the laws on regulated purchases No. 44-FZ and No. 223-FZ when reorganizing legal entities on the example of transformation of a unitary enterprise into a joint-stock company. The subject of this research is the system of regulated procurement by certain types of legal entities, and purchases implemented within the contract system of the Russian Federation. The subject of the study is the organization of the procurement system by the customer during the transition from the rules established by the Law No. 44-FZ to the rules established by the Law No. 223-FZ (and vice versa). To achieve this purpose, the following research objectives are set: 1) to analyze the issues occurring during the transition period when reorganizing legal entities;2) to systematize the results of the research;3) to suggest measures to improve the process of changing the system of regulated purchases by the customer. The authors studied the issues of applying the laws on regulated purchases No. 44-FZ and No. 223-FZ when reorganizing legal entities, as well as when changing normative regulation as referred to the procurement system used by a legal entity. The analysis of the process of reorganization of a unitary enterprise into a joint-stock company in the form of transformation regarding the transition from the Law No. 44-FZ to the Law No. 223-FZ has been conducted, issues identified and a set of recommendations for their solution developed.
\end{abstract}

Civil legislation of the Russian Federation provides for the possibility of reorganization of a legal entity in the form of merger, accession, division, separation, and transformation by the decision of its founders (members) or the body of a legal entity authorized by a charter document [1]. In the situation that such a legal entity was obliged to apply the relevant laws when organizing the procurement of goods, works and services (the Federal Law No. 223FZ of 18.07.2011 "On Procurement of Goods, Work, Services by Individual Types of Legal Entities" (hereinafter - the Law No. 223-FZ, the Procurement Law) or the Federal Law No. 44-FZ of 05.04.2013 "On the contract system in the procurement of goods, works and services for the provision of state and municipal needs" (hereinafter - the Law No. 44-FZ, the Contract system), or it acquired such a duty as a result of reorganization, or it changed the law regulating the procurement activity (for example, moved from the Law No. 223-FZ

\footnotetext{
*Corresponding author: pvv@ex.istu.edu
} 
to the Law No. 44-FZ, or vice versa), then it faces a number of unresolved issues in connection with such a transition.

Let us consider these problems on the example of a unitary enterprise. In our opinion, the frequency of changes that occurs in the procurement activities of unitary enterprises, as well as the speed with which they are accomplished, is unacceptable in the life-span of the company for the normal organization of procurement logistics:

- from 2012 (for Municipal Unitary Enterprises (MUEs) - from 2014) to 2016, the procurement of goods, works, and services of such organizations was regulated by the Law No. 223-FZ;

- from 1 January 2017, the Federal Law No. 321-FZ of 03.07.2016 "On Amendments to Certain Legislative Acts of the Russian Federation on Procurement of Goods, Works, Services to Ensure State and Municipal Needs and the Needs of Certain Types of Legal Entities" excluded them from customers under the Law No. 223-FZ, and transferred to the customers under the Law No. 44-FZ, leaving only insignificant opportunities to work within the rules of procurement for corporate customers in comparison with budget institutions, that is illustrated in the Table 1.

Table 1. Comparison of the cases when the budget institutions (BI) and the State Unitary Enterprises (SUE) and Municipal Unitary Enterprises (MUE) can apply the Law No. 223-FZ.

\begin{tabular}{|c|c|}
\hline $\begin{array}{c}\text { SUE } \\
\text { (Part 1, } 2 \text { of the Article } 15 \text { of the Law No. } \\
\text { 44-FZ, Section 4, Part } 2 \text { of the Article } 1 \text { of } \\
\text { the Law No. 223-FZ) }\end{array}$ & $\begin{array}{c}\text { SUE (MUE) } \\
\text { (Part 2.1 of the Article 15 of the Law No. } \\
\text { 44-FZ, Section 5, Part } 2 \text { of the Article } 1 \\
\text { of the Law No. 223-FZ) }\end{array}$ \\
\hline $\begin{array}{l}\text { at the expense of funds from other income- } \\
\text { generating activities (with the exception of } \\
\text { the means of compulsory medical } \\
\text { insurance); }\end{array}$ & --- \\
\hline $\begin{array}{l}\text { at the expense of grants (foreign, from the } \\
\text { Russian Federation budget, unless the } \\
\text { grantors have defined other conditions); }\end{array}$ & $\begin{array}{l}\text { at the expense of grants (foreign, from the } \\
\text { Russian Federation budget, unless the } \\
\text { grantors have defined other conditions); }\end{array}$ \\
\hline $\begin{array}{l}\text { in case if BI, executing the contract, attracts } \\
\text { other entities for the performance of this } \\
\text { contract }\end{array}$ & $\begin{array}{l}\text { in case if SUE (MUE), executing the } \\
\text { contract, attracts other entities for the } \\
\text { performance of this contract NB: except for } \\
\text { the contracts concluded in accordance with } \\
\text { clause } 2 \text { Part } 1 \text { of the Article } 93 \text { of the Law } \\
\text { No. } 44-F Z\end{array}$ \\
\hline
\end{tabular}

The subsequent adjustments, undertaken by the federal legislator, show that in relation to a number of customers the decision was hasty:

1) First, the Federal Law No. 474-FZ "On Amendments to Certain Legislative Acts of the Russian Federation" dated December 28, 2016 excluded "federal state unitary enterprises (FSUE) that are essential for securing the rights and legitimate interests of citizens of the Russian Federation, the defense capability and security of the state, the list of which is approved by the Government of the Russian Federation in agreement with the Administration of the President of the Russian Federation" (according to the Order of the Government of the Russian Federation No. 2931 of December 31, 2016, 123 such FSUE are designated up to nowadays);

2) Further, the Federal Law No. 108-FZ of 07.06.2017 "On Amendments to the Articles 1 and 8 of the Federal Law "On Procurement of Goods, Work, Services by Certain Types of 
Legal Entities" and the Articles 15 and 112 of the Federal Law "On the Contract System in the Sphere of Procurement of Goods, Works, Services for Provision of State and Municipal Needs" from June 7, 2017 makes it possible for to SUE and MUE, which are pharmacy organizations, to work under the Law No. 223-FZ without raising funds from the relevant budgets of the Russian Federation budgetary system (it is clear that the pharmacy organization cannot survive on the competitive market, buying the products sold under the provisions of the Law on the Contract System).

The remaining unitary enterprises are divided into two groups:

1) Those continuing to carry out purchases under the rules provided for by the Law No. 44-FZ;

2) Those that decided to reorganize into the business entity, in particular, for the reasons and with the purpose to return their procurement activity under regulation of the Law No. 223-FZ.

In accordance with the Russian Federation legislation on privatization [2], a unitary enterprise can be transformed into a joint-stock company or a limited liability company. Privatization of a unitary enterprise into a joint-stock company is a lengthy process.

According to the Order of the Government of the Russian Federation No. 227-r dated 08.02.2017 "On Approving the Forecast Plan for the Privatization of Federal Property and the Main Directions for the Privatization of Federal Property for 2017 - 2019", the list of federal state unitary enterprises planned for privatization in 2017-2019 included 20 legal entities. In the Forecast Plan of Privatization of the municipal property in the city of Irkutsk for 2017 - 2019, only three legal entities were included in the list of municipal unitary enterprises planned for privatization in 2017 (later one of them was excluded from the list).

Let us consider a number of practical moments and consequences for the second group:

1. After the entry in the Unified State Register of Legal Entities (hereinafter referred as the USRLE) is made, the question arises: how and when the work under the Law No. 223$\mathrm{FZ}$ is to be resumed?

For example, from 01.01.2014 MUE carried out procurement activities under the Law No. 223-FZ. Starting from 01.01.2017, the MUE carried out purchases in accordance with the requirements of Paragraph 2.1, the Article 15 of the Law No. 44-FZ. On September 14, 2017, an entry was made in the USRLE on the termination of activities of the Municipal Unitary Enterprise by reorganizing it in the form of transformation and creating a Joint Stock Company.

How to apply the normative legal acts regulating the procurement activity of the JointStock Company in connection with its reorganization in the form of transformation?

Be believe that the following answer seems to be correct: "Entities obliged to apply the Law No. 223-FZ are listed in the Paragraph 2 of the Article 1 of the Law No. 223-FZ.

The Section 1 of the Paragraph 2 of the Article 1 of the Law No. 223-FZ refers to such business entities, in which the share of participation of the Russian Federation, the Russian Federation constituent entity, and the municipal entity exceeds $50 \%$ in their charter capital.

Since in the authorized capital of the Joint-Stock Company $100 \%$ belongs to the city administration, when making purchases of goods, works, services (except for the cases listed in the Paragraph 4 of the Article 1 of the Law No. 223-FZ), the Joint-Stock Company shall be governed by the provisions of the Law No. 223-FZ.

However, according to the Paragraph 5 of the Article 8 of the Law No. 223-FZ: "Customers specified in the sections 1 to 3 of the Paragraph 2 of the Article 1 of this Federal Law, and created after the date of enforcement of this Federal Law, must approve the provision on procurement within three months from the date of their registration in the USRLE. If during the specified period such customers would not place the approved procurement regulations in accordance with the requirements of this Federal Law, customers are guided by the provisions of the Law No. 44-FZ when making procurement". 
Herewith, the application of the previous procurement provisions developed for the municipal unitary enterprises may be qualified as a violation of the Law No. 223-FZ, because the procedure for approving this document differs depending on the organizational and legal form of the customer [3].

According to the Article 57 of the Civil Code of the Russian Federation, "The reorganization of a legal entity (merger, accession, division, separation, transformation) may be carried out by the decision of its founders (members) or the body of a legal entity authorized by a constituent document", "A legal entity is considered reorganized, with the exception of cases of reorganization in the form of accession, from the moment of state registration of legal entities created as a result of reorganization".

In accordance with Paragraph 5 of the Article 58 of the Civil Code of the Russian Federation "When a legal entity of one organizational legal form is transformed into a legal entity of another organizational and legal form, the rights and obligations of the reorganized legal entity with respect to other entities do not change, with the exception of rights and obligations referring to the founders (members), the change of which is caused by the reorganization".

According to the Paragraph 8 of the Article 51 of the Civil Code of the Russian Federation "A legal entity is considered created, and data on a legal entity are considered included into the USRLE from the date of making of the relevant entry into this Register".

The entry on the establishment of the Joint Stock Company by reorganization in the form of transformation was made to the USRLE on September 14, 2017.

Thus, the Joint-Stock Company must approve, taking into account the Paragraph 5 of the Article 8 of the Law No. 223-FZ, the procurement provisions within three months from the date of registration in the Unified State Register of Legal Entities (i.e. until December 14, 2017) and place it on the official site of a unified information system in the sphere of procurement of goods, works, and services to ensure state and municipal needs (hereinafter - the unified information system, the UIS).

If within the specified period the Joint-Stock Company will not place the approved procurement regulations, in accordance with the requirements of the Law No. 223-FZ, the Joint-Stock Company shall be guided in its procurement by the provisions of the Law No. 44-FZ regarding the definition of the supplier (contractor, performer) to the day of placement of the approved procurement regulations in accordance with the requirements of the Law No. 223-FZ.

During the transition period (within three months: from September 14, 2017 to December 14, 2017) when making procurement, the Joint-Stock Company is entitled to be guided by the provisions of the Civil Code of the Russian Federation.

It should be noted that such recommendations are found in most cases. The positions of the Ministry of Economic Development of Russia on similar issues can be found in the letters of the Ministry No. OG-D28-9983 of 19.08.2016, No. D28i-1431 of 03.06.2015, and No. D28i-2880 of 28.10 .2016

However, there is also a very controversial decision of the court (controversial, since the decision of the court is not supported by the regulatory framework), which expresses the position on the need to be guided by the provisions of the Law on the Contract System in determining the supplier in the transition period [3].

2. How to complete the purchases that started under the Law No. 44-FZ?

As mentioned above, in accordance with the Paragraph 5 of the Article 58 of the Civil Code of the Russian Federation "When a legal entity of one organizational legal form is transformed into a legal entity of another organizational and legal form, the rights and obligations of the reorganized legal entity with respect to other entities do not change, with the exception of rights and obligations in respect of the founders (members), the change of which is caused by the reorganization". 
Based on that, it can be assumed that the purchases that started under the Law No. 44-FZ must be completed in accordance with the rules of the Contract System, including the reports on the implementation of contracts, information on the execution of contracts in the register of contracts in the UIS, etc.

However, this is technically impossible, because the Order No. 27n of the Russian Federation Treasury dated December 30, 2015 "On Approving the Procedure for Registration in the Unified Information System in the Sphere of Procurement ..." does not provide for the possibility to work on the official website of the UIS for legal entities in the case that interests us. Could this serve as a reason to believe that the customer does not need completing the procurement begun under the Law No. 44-FZ in accordance with the rules of this law? We believe that the answer is No. However, this issue is not regulated in the legislation.

The Ministry of Economic Development and Trade of the Russian Federation in the letter No. D28i-2279 "On the performance of contracts in the field of procurement by an autonomous institution - the legal successor of a transformed budget institution" (the authors could not find similar explanations for the reorganization of the unitary enterprise in the form of transformation into a joint-stock company) dated 07.09.2016 stipulates: "Thus, if the procurement is commenced in accordance with the provisions of the Law No. 223-FZ or the Law No. 44-FZ, the transformed entity, regardless its organizational and legal form, shall continue applying the norms of the law, according to which the purchase began.

So, the legal successor has the right to take a decision on termination of contracts concluded prior to the reorganization of the legal entity, or on continuation of the performance of contracts by the transformed legal entity". This letter also points out: "It should be noted that the UIS provides for the following functionality by the successor on the contracts:

- blocking the organization (budgetary institution) by the organization that provides services for users of the unified information system with the indication of the successor organization (autonomous institution);

- succession to contracts chosen by the successor organization". However, in case of reorganization in the form of transformation and creation of a joint-stock company, it was not possible to use such functionality. There is no other option for placing such information on behalf of the customer provided by the law. In the user manual of the official website of the UIS, the algorithm of actions for the situation in question has not been found, that is, the technical mechanism for establishing the succession has not been realized.

In practice, the customer sent to the UIS operator the information necessary for the placement to the UIS with a request to post it on the official website (which, in fact, did not happen), and also made a request to the technical support service of the official site of the UIS with a proposal for its improvement by implementing the technical capability of fulfilling the customer's duty on keeping the register of contracts in accordance with sections $8,10,11,13,15$ of the Paragraph 2 of the Article 103 of the Law No. 44-FZ on behalf of the organization of the legal successor registered in the UIS in the personal cabinet under the Law № 223- FZ.

At the time of writing of this paper, the proposal was not implemented.

3. Is it necessary to complete the obligations that started under the Law No. 44-FZ on supporting small business entities (hereinafter referred to as SME) and socially-oriented noncommercial organizations (hereinafter referred to as SONCO) in accordance with the Article 30 ?

It is obvious that after the entry on the termination of activities of a unitary enterprise through reorganization in the form of transformation and the creation of a joint-stock company through reorganization in the form of conversion is introduced into the USRLE, there are no possibilities to execute requirements provided in the Article 30 of the Law No. 44-FZ. 
As a consequence, the following questions arise:

3.1) In the example given when describing the first situation of this article, the Unitary Enterprise has worked as a customer under the Law No. 44-FZ for 8.5 months, while the obligation to support SME and SONKO in accordance with the Paragraph 1 of the Article 30 of the Law No. 44-FZ is calculated on the basis of the whole year.

Example:

During the period of work under the Law No. 44-FZ (for 8.5 months), the Unitary Enterprise conducted the purchases shown in Table 2:

Table 2. Purchases realized by the Municipal Unitary Enterprise for the period of application of the Law No. 44-FZ.

\begin{tabular}{|c|c|c|c|c|c|}
\hline № & Means & $\begin{array}{c}\text { Initial } \\
\text { (maximu } \\
\mathrm{m}) \\
\text { contract } \\
\text { price } \\
\text { rubles } \\
\end{array}$ & $\begin{array}{l}\text { Advantages for SMEs } \\
\text { (SONCO) in accordance } \\
\text { with the Law No. 44-FZ }\end{array}$ & Result & $\begin{array}{l}\text { Contract } \\
\text { price, } \\
\text { rubles }\end{array}$ \\
\hline 1 & $\begin{array}{l}\text { Electronic } \\
\text { auction }\end{array}$ & $\begin{array}{l}119000 \\
0\end{array}$ & $\begin{array}{l}\text { Paragraph 1, Part 1, } \\
\text { Article } 30\end{array}$ & $\begin{array}{l}\text { Did not take } \\
\text { place, the } \\
\text { contract is } \\
\text { concluded } \\
\text { with the sole } \\
\text { supplier }\end{array}$ & 1190000 \\
\hline 2 & $\begin{array}{l}\text { Open } \\
\text { competition }\end{array}$ & $\begin{array}{l}723366 \\
0\end{array}$ & Not defined & Took place & 5450000 \\
\hline 3 & $\begin{array}{l}\text { Electronic } \\
\text { auction }\end{array}$ & $\begin{array}{l}245808 \\
00\end{array}$ & $\begin{array}{l}\text { Paragraph 2, Part } 1, \\
\text { Article } 30, \text { in the amount } \\
\text { of } 15 \% \text { of the price of the } \\
\text { contract }\end{array}$ & $\begin{array}{l}\text { Did not take } \\
\text { place, the } \\
\text { contract is } \\
\text { concluded } \\
\text { with the sole } \\
\text { supplier }\end{array}$ & 24580800 \\
\hline 4 & $\begin{array}{l}\text { Open } \\
\text { competition }\end{array}$ & 264000 & $\begin{array}{llll}\text { Paragraph } & 1, & \text { Part } & 1, \\
\text { Article } 30 & & & \\
\end{array}$ & Took place & 140000 \\
\hline
\end{tabular}

It turns out that during the period under review the customer supported SME and SONKO in the amount of $12.68 \%$.

Thus, if during the period of work under the Law No. 44-FZ the amount of support for SME and SONCO was less than $15 \%$, will the officials of the customer be liable?

According to the Paragraph 11 of the Article 7.30 of the Code of Administrative Offenses "The procurement of goods, works, services for the provision of state and municipal needs from SMP and SONKO in the amount less than the amount stipulated by the legislation of the Russian Federation on the Contract System in the procurement sphere shall entail the imposition of an administrative fine on officials in the amount of fifty thousand rubles", while "The time for committing an administrative offense provided in the Paragraph 11 of this article is the end date of the calendar year" (note 2 to the Article 7.30 of the Code of Administrative Offenses). In this regard, we believe that we should talk about the absence of an administrative offense.

In our opinion, in order to avoid the emergence of controversial situations, this issue must be resolved in the legislation. 
3.2) Is it necessary to prepare a report on the volume of purchases from SME and SONCO and place it in the UIS before April 1 ? Our opinion on this issue is similar to that referred to the Situation No. 2.

4. Is it needed to support the entities of the small and medium-sized businesses (hereinafter referred to as ESMEs) within the framework of the Law No. 223-FZ in the year, in that the legal entity was transformed?

In the Paragraph 2 of the Resolution of the Government of the Russian Federation No. 1352 of December 11, 2014, a list of entities obliged to support ESME is provided. Suppose that the customer that appeared after the transformation finds himself in this list. Is he obliged to apply the Decree of the Government of the Russian Federation of 11.12.2014 No. 1352 during the remaining period of the year, in which the transformation took place? So, in the example referring to the first situation in this paper, the remaining period of the year will be two weeks. The answer to this question is contained in the Decree of the Government of the Russian Federation of December 11, 2014 No. 1352 (Paragraph 3 of the Regulations on the Specifics of the Participation of the ESME ...): "The clients registered in the Unified State Register of Legal Entities after enforcement of this Regulation, must apply this Regulation from January 1 of the year following the year in which such customers were registered".

5. How to plan purchases in the year (for the remainder of the year), in which the transformation of a legal entity has occurred?

Neither the Law No. 223-FZ, nor the bylaws regulate the specifics of planning purchases of goods, works, and services by new customers. According to the general rules "Placing a procurement plan for goods, works, and services, and information on making changes to the UIS is carried out within 10 calendar days from the date of approval of the plan, or making changes to it. The procurement plan is to be placed in the UIS no later than December 31 of the current calendar year" [4], while "the customer places in the UIS a plan for the procurement of goods, works, and services for a period not less than one year" (Part 2 of the Article 4 of the Law No. 223-FZ). Thus, it is not allowed to plan only for a part of that year, when the customer started working under the Law No. 223-FZ. In our opinion, in the example considered in this paper, planning for the remainder of 2017 and for the entire 2018 will be the optimal way for the customer.

In the meantime, the process of returning of some customers-unitary enterprises to the Law No. 223-FZ continues:

- According to the Draft Law No. 371836-7, it is proposed to allow working under the Law No. 223-FZ "to state and municipal unitary enterprises without attracting funds of the relevant budgets of the budgetary system of the Russian Federation";

It is also proposed to allow other entities carrying out a part of the procurement according to the rules of the Law No. 223-FZ:

- The website <regulation.gov.ru> posted a notice about the beginning of drafting the Federal Law [6] by the Ministry of Industry and Trade, according to which it is planned to withdraw purchases conducted by federal state enterprises and federal treasury enterprises at their own expense from the sphere of regulation of the Law No. 44-FZ.

The authors believe that these changes will improve the efficiency of procurement. It is assumed that the innovations should enter into force in December of this year.

However, the opposite tendencies also take place:

- On the website <regulation.gov.ru>, the discussion of the Draft Federal Law "On Amendments to the Federal Law "On the Contract System in the Sphere of Procurement of Goods, Works and Services for Ensuring State and Municipal Needs" and the Federal Law "On Procurement of Goods, Work, and Services by Certain Types of Legal Entities" (ID01/05 / 07-16 / 00050933) was completed, according to which autonomous organizations are proposed to be transferred to the customers under the Law No. 44-FZ; 
- the Government considered the idea of the Ministry of Finance to extend the Law on the Contract System to the purchases of the state companies, state corporations and companies with $100 \%$ state participation [5].

It seems that the rotation of customers from the Law No. 223-FZ to the Law No. 44-FZ and vice versa, both because of their reorganization, and because of the regulatory changes, is the prospect of the next years of work. In this regard, we have worked out the following proposals aimed at improving the relevant process of the customers' transition:

- At the legislative level, it is needed to approve the algorithms for transferring the purchasing activity of the customers from the Law No. 223-FZ to the Law No. 44-FZ, or vice versa;

- to approve the general rule of the possibility of transferring the purchasing activity of the customers from the Law No. 223-FZ to the Law No. 44-FZ, or vice versa, only from the year following the occurrence of the event, in connection with which such a transition takes place (with possible exceptions). This measure will resolve the issues of procurement planning, observing the necessary quotas for support of certain participants in procurement.

- to improve the UIS by implementing the technical capability to fulfill the customer's outstanding obligations in accordance with the Law No. 44-FZ on behalf of the legal successor organization registered in the UIS in the personal cabinet under the Law No. 223FZ (or vice versa). Thus, it will technically be feasible to realize the possibility of the legal succession of the organization (predecessor), that worked and registered in the personal cabinet under the Law No. 44-FZ, with the operating organization (successor) registered in the UIS in the personal cabinet under the Law No. 223-FZ (or vice versa).

As for the transfer of certain legal entities from the subjects of the Law on Procurement to the subjects of the Contract System (or vice versa), it would be desirable that decisions, so important for the fate of some legal entities in particular, and for the well-being of the country as a whole, are to be made only after a thorough justification of the economic feasibility and comprehensive risk assessment for the long term perspective [7].

\section{References}

1. Collection of Legislation of the Russian Federation, The Civil Code of the Russian Federation (Part One) of 30.11.1994 N 51-FZ (Moscow, 1994)

2. Rossiyskaya Gazeta, Federal Law of December 21, 2001 N 178-FZ On the Privatization of State and Municipal Property (Moscow, 2002)

3. Arbitration Court of the East Siberian District, Decree of the Arbitration Court of the East Siberian District of 21.03.2016 N F02-972/2016 in the case N A33-10235/2015 (ConsultantPlus, Moscow, 2016)

4. Government of Russia, Resolution of the Government of the Russian Federation of 10.09.2012 N 908 on approval of the Regulation on the placement of information on procurement in a single information system (Collection of Russian legislation, 2012)

5. Kommersant, The government will check who supported (https://www.kommersant. $\mathrm{ru} / \mathrm{doc} / 3535911,2018$ )

6. Notification of the beginning of the development of the draft federal law (http://regulation.

gov.ru/projects\#StartDate=15.3.2018\&EndDate=20.3.2018\&npa=79109, 2018)

7. S. Yu. Kopelchuk, M. V. Matveeva, Proceedings of Universities: Investment. Construction. Real Estate, 2(5), 21-25 (2013) 